\title{
Enzymatic removal of plant residues from wool: Application of experimental design techniques for optimization parameters
}

\author{
Isabel C. Gouveia ${ }^{\mathrm{a}, \mathrm{c}, *}$, José M. Fiadeiro ${ }^{\mathrm{a}, \mathrm{c}}$, João A. Queiroz ${ }^{\mathrm{b}, \mathrm{c}}$ \\ a Departamento Têxtil, Universidade da Beira Interior, 6201-001Covilhã, Portugal \\ b Departamento de Química, Universidade da Beira Interior, 6201-001Covilhã, Portugal \\ ' Unidade dos Materiais Têxteis e Papeleiros, Universidade da Beira Interior, 6201-001Covilhã, Portugal
}

\section{A R T I C L E I N F O}

\section{Article history:}

Received 13 August 2007

Received in revised form 7 March 2008

Accepted 17 April 2008

\section{Keywords:}

Biodegradation

Cell-wall-polysaccharides

Enzyme technology

Response surface methodology

Modeling

Optimization

\begin{abstract}
A B S T R A C T
This study was undertaken to find the optimum conditions of a new enzymatic process to remove plant residues from wool. Commercial enzymatic preparations of Celluclast $1.5 \mathrm{~L}$ and Pectinex Ultra SP-L were selected in order to hydrolyze the polysaccharides in primary plant cell walls and middle lamella, resulting into more fragile residues easier to be removed. Since it was intended to define the optimal conditions for enzyme application, a four-factor central composite design was selected to study the effects of $\mathrm{pH}$, temperature, enzyme concentration and wetting agent concentration, on the two selected responses, i.e., soluble reducing sugars (RS) and alkali solubility (AS) of wool to detect plant degradation and to evaluate wool quality, respectively. Results demonstrated that enzyme concentration was the most significant effect in plant residues degradation. A total enzyme concentration loading of $20 \mathrm{~mL}$ of both diluted enzymatic preparations in equal parts per $1 \mathrm{~L}$ of incubation solution $(42.970 \mathrm{U} / \mathrm{L}$ of Celluclast preparation and PG 29.3 nkat/L + PME $2.537 \mathrm{nkat} / \mathrm{L}$ of Pectinex preparation), yielded an equivalent amount of $240.127 \mathrm{mg}$ of glucose per $1.0 \mathrm{~g}$ of plant residue, at the optimal conditions: $40.56^{\circ} \mathrm{C}, \mathrm{pH} 4.0$ and $1 \mathrm{~mL}$ Plurafac/L. SEM analysis has indicated an identical and important degradation of the plant residues, when compared to the conventional carbonization process, and wool quality has been preserved.
\end{abstract}

(c) 2008 Elsevier B.V. All rights reserved.

\section{Introduction}

Wool carbonization, a process to remove plant residues from wool, uses sulphuric acid and has undesirable effects concerning either the environment as the quality of wool [1-3]. The complete degradation of plant residues requires high amounts of sulphuric acid (5-7\%) as well as high temperatures $\left(120-130^{\circ} \mathrm{C}\right)$. Lack of control in process parameters like moisture content before baking at high temperatures and heterogeneous acid distribution on fabrics can damage wool fibers, may cause processing problems and is non-environment friendly.

Plant residues of wool have their origin especially in the leaves, stems and seeds of plants which are morphology composed of thousands of plant cells disposed on several layers forming the

Abbreviations: RS, soluble reducing sugars; AS, alkali solubility of wool; DNS, 3,5-dinitrosalicilic acid; PG, polygalacturonases; PME, pectin methylesterase; EG, endoglucanases; XYL, xylanases; MAN, mannanases; $\beta$-GAL, $\beta$-galactosidases; $\beta$ GLU, $\beta$-glucosidases; $\alpha$-ARA $\alpha$, -arabinases; RSM, response surface methodology.

* Corresponding author at: Departamento Têxtil, Universidade da Beira Interior, 6201-001Covilhã, Portugal. Tel.: +351 275319825; fax: +351 275319723.

E-mail address: igouveia@ubi.pt (I.C. Gouveia). fundamental plant tissues [4]. The plant cell wall is a strong fibrillar network composed by 3 types of layers: the middle lamella, the primary wall and the secondary wall $[4,5]$. According to current cell wall models, the primary wall consists of cellulose microfibrils interconnected or tethered together by hemicellulosic polysaccharides, forming a cellulose/hemicellulose network [5-7]. In addition, the primary wall contains another network mainly composed by the pectic polysaccharides: homogalacturonan, rhamnogalacturonan I and rhamnogalacturonan II [8,9]. Small amounts of structural proteins can also be found in all plant primary cell walls. The secondary plant cell wall sometimes has a composition nearly identical to that of the earlier-developed wall. More commonly however, additional substances especially lignin are found in the secondary wall $[5,10]$. A specialized region associated with the cell walls of plants is the middle lamella. Rich in pectin's, the middle lamella is shared by neighboring cells and cements them firmly together.

The complete enzymatic hydrolysis of cellulose and other polysaccharide such us, for example, arabinogalactans, and glucoronoxylans, depending on plant type (dicotyledonous or monocotyledonous, respectively), requires the combined catalytic action of several cellulases with different substrate specificities $[9,11,12]$. The cellobiohydrolases (EC 3.2.1.91) cleave cellulose units at the reducing and non-reducing ends of the cellulose backbone, 
liberating disaccharides like cellobiose. Endoglucanases (EC 3.2.1.4) cut at random at internal amorphous sites in the cellulose or xyloglucan chains, generating oligosaccharides of various lengths providing new chain ends [11,13]. The $\beta$-glucosidase (EC 3.2.1.21) hydrolyses either $\beta$-D-glucosyl or $\beta$-D-xylosyl or other disaccharides to glucose and xylose and the corresponding monosaccharide [14].

Several enzymes are known to catalyze pectin degradation providing cell wall disassembly. Pectin-main-chain degrading enzymes can be divided into hydrolases and lyases [14]. Pectin methylesterase (EC 3.1.1.11) catalyzes the deesterification of methyl ester linkages of galacturonan backbone of pectin, yielding methanol and pectin with lower esterification degree (acidic pectins) [16-20]. The resulting pectin is than depolymerized: (1) by hydrolysis, using polygalacturonases (PG) of endo-acting type (EC 3.2.1.15), which hydrolyses $\alpha-1.4$ linkages between adjacent galacturonic acid units at random, and exo-acting type (EC 3.2.1.67) which hydrolyses from the ends of the polysaccharide chains $[15,19,21]$ or: (2) by trans-elimination reaction, using endo-polymethylgalacturonate lyase (EC 4.2.2.9) and exopolygalacturonate lyase (EC 4.2.2.2) [14,18,20,21,22].

Response surface methodology (RSM) is a powerful technique for testing multiple process variables because fewer experimental trials are needed as compared to the "one-factor-at-a-time" method [23-24]. In addiction, significant interactions between the variables can be identified and quantified by this technique. The optimization of medium conditions or process parameters is therefore possible and widely performed by using a Central Composite Design (CCD) or Box-Wilson Design [25-27].

In this way, the investigation of the ability of specific enzymes as an ecological, efficient and safe alternative to the chemical carbonization of wool is of utmost importance. Moreover, because statistical experimental designs provide an efficient approach to process optimization, being especially suitable in accounting for the interactions and identifying the more significant parameters or factors in a certain process, optimization was made using the response surface methodology.

\section{Experimental}

\subsection{The enzymes}

Considering the plant cell wall composition, current cell wall models regarding polysaccharide arrangement and cell arrangement in plant tissues, the selection of enzymes was made in order to provide: (1) hydrolysis of the pectic and hemicellulosic cement between cells making them more susceptible to disassembly and desegregation; (2) hydrolysis of the primary walls.

Therefore, a commercial Trichoderma reesei enzyme preparation containing cellulases and hemicellulases: Celluclast $1.5 \mathrm{~L}$ (42.970 FPU/mL) and one Aspergillus aculeatus derived enzyme preparation containing Pectinases and hemicellulases: Pectinex Ultra SPL (PG 29300 nkat/L, PME 2537 nkat/L, EG 1653 nkat/L, XYL 900 nkat/L, MAN 16160 nkat/L, $\beta$-GAL 1464 nkat/L, $\beta$-GLU 8 nkat/L e $\alpha$-ARA $715 \mathrm{nkat} / \mathrm{L}$ ) [28], were used. Both enzyme preparations are from Novozymes.

\subsection{The substrate}

The substrate: raw wool was simulated to provide the same proportion and type of plant residues somehow difficult to achieve in the native state. It was prepared by collecting the plant residues from card waste and separated manually. The residues were then evenly blended to wool $(21 \mu \mathrm{m})$ in the proportion of $3.5 \%, \mathrm{w} / \mathrm{w}$
Table 1

Chemical composition of the plant residues (dry weight)

\begin{tabular}{lr}
\hline Composition & $(\%)$ \\
\hline Cellulose & 54.5 \\
Hemicellulose & 22.4 \\
Total pectin's & 9.5 \\
Lignin & 8.2 \\
Proteins & 2.0 \\
Ashes & 2.1 \\
Other & 1.3 \\
\hline
\end{tabular}

(plant residues/wool), since it is a current blend found in natural raw wool.

Chemical composition of the plant residues was determined in a technical lab specialized in feedstock nutrition, using the appropriate methods [29-32], in order to select the most appropriate enzymes. The major components found were, as expected, cellulose and hemicelluloses. Total pectin's and lignin were also identified, being the pectin content in a superior's amount (see Table 1).

\subsection{Methods}

\subsubsection{Enzymatic treatments}

Enzymatic treatments with Celluclast and Pectinex were carried out in a Mathis dyeing machine (model BFA12) as follows: $0.1 \mathrm{~g}$ of substrate (raw wool) was incubated in $5 \mathrm{~mL}$ of buffer solution (sodium acetate $50 \mathrm{mM}$ with $2 \%(\mathrm{v} / \mathrm{v})$ EDTA $1.8 \mathrm{mM}$ ) during $4 \mathrm{~h}$, with mild mechanical agitation (20 rpm).

These fixed optimal conditions were settled after preliminary studies were performed. Effect of $\mathrm{pH}$, temperature, enzyme concentration and of an non-ionic wetting agent concentration, to prevent binding of enzymes to residual lignin and wool further damage (Plurafac LF 400, from BASF), were studied using the combinations resulted from the appropriate experimental design as shown in Tables 2 and 3.

Diluted solutions of each enzyme preparations were made by diluting the preparation in the acetate buffer solution $50 \mathrm{mM}$, at the corresponding $\mathrm{pH}$ for each experimental level, in a ratio of 1:10 (enzyme:buffer solution).

\subsubsection{Analytical assays}

Enzymatic activity was analyzed by the increase in the number of reducing groups after incubation. The reducing groups of the soluble released sugars were determined with the colorimetric method using the 3,5-dinitrosalicilic acid (DNS) [33,34], using glucose solutions as standards. The DNS method has been widely used with success to evaluate the digestion of polysaccharides of plant residues and biomass by cellulolitic and ligno-cellulolytic enzymes [35-38]. In this study, we wanted to detect minor variations in plant degradation to provide a good correlation with enzyme activity

Table 2

Coded and actual levels of the design factors

\begin{tabular}{lccccc}
\hline Factors & \multicolumn{2}{l}{ Levels $^{\mathrm{b}}$} & & & \\
\cline { 2 - 6 } & -2 & -1 & 0 & +1 & +2 \\
\hline A: $\mathrm{pH}$ & 3.0 & 3.5 & 4.0 & 4.5 & 5.0 \\
B: Temperature $\left({ }^{\circ} \mathrm{C}\right)$ & 35 & 40 & 45 & 50 & 55 \\
C: Enzymes $(\mathrm{mL} / \mathrm{L})$ & 5 & 10 & 15 & 20 & 25 \\
$D:$ : Plurafac $(\mathrm{mL} / \mathrm{L})$ & 0 & 0.5 & 1.0 & 1.5 & 2.0 \\
\hline
\end{tabular}

a Enzyme concentration means the addition of Celluclast and Pectinex diluted solutions, in equal proportion, resulted from the analysis made in a previous study using a full factorial design with both enzymes as factors and the resulting reducing sugars (RS) as response [30].

b Levels based on a face-centred Central Composite Rotable Design. The code variable level limits were based on preliminary investigations. 
Table 3

Design layout and results of the Central Composite Design and carbonized wool

\begin{tabular}{|c|c|c|c|c|c|c|c|c|}
\hline Yates order & Runs & Factor & $\mathrm{pH}(A)$ & Temperature $(B)\left({ }^{\circ} \mathrm{C}\right)$ & Enzyme $(C)(\mathrm{mL} / \mathrm{L})$ & Wetting agent $(D)(\mathrm{mL} / \mathrm{L})$ & $\mathrm{RS}(\mathrm{mg} / \mathrm{g})$ & AS (\%) \\
\hline 2 & 1 & Factorial & +1 & -1 & -1 & -1 & 180.4 & 12.8 \\
\hline 21 & 2 & Axial & 0 & 0 & -2 & 0 & 110.6 & 12.6 \\
\hline 9 & 3 & Factorial & -1 & -1 & -1 & +1 & 140 & 12.4 \\
\hline 10 & 4 & Factorial & +1 & -1 & -1 & +1 & 190.5 & 12.5 \\
\hline 12 & 5 & Factorial & +1 & +1 & -1 & +1 & 140.9 & 12.6 \\
\hline 28 & 6 & Centre & 0 & 0 & 0 & 0 & 200.5 & 12.8 \\
\hline 4 & 7 & Factorial & +1 & +1 & -1 & -1 & 140 & 13 \\
\hline 24 & 8 & Axial & 0 & 0 & 0 & +2 & 210.2 & 12.5 \\
\hline 17 & 9 & Axial & -2 & 0 & 0 & 0 & 130 & 12.4 \\
\hline 26 & 10 & Centre & 0 & 0 & 0 & 0 & 220 & 12.6 \\
\hline 14 & 11 & Factorial & +1 & -1 & +1 & +1 & 240 & 12.4 \\
\hline 3 & 12 & Factorial & -1 & +1 & -1 & -1 & 120.9 & 13.3 \\
\hline 15 & 13 & Factorial & -1 & +1 & +1 & +1 & 210 & 12.8 \\
\hline 13 & 14 & Factorial & -1 & -1 & +1 & +1 & 240.6 & 12.6 \\
\hline 6 & 15 & Factorial & 1 & -1 & +1 & -1 & 230 & 12.8 \\
\hline 5 & 16 & Factorial & -1 & -1 & +1 & -1 & 230.2 & 12.9 \\
\hline 27 & 17 & Centre & 0 & 0 & 0 & 0 & 200.4 & 12.6 \\
\hline 1 & 18 & Factorial & -1 & -1 & -1 & -1 & 130.4 & 12.8 \\
\hline 18 & 19 & Axial & +2 & 0 & 0 & 0 & 180.5 & 12.6 \\
\hline 25 & 20 & Centre & 0 & 0 & 0 & 0 & 200 & 12.5 \\
\hline 11 & 21 & Factorial & -1 & +1 & -1 & +1 & 130 & 12.6 \\
\hline 22 & 22 & Axial & 0 & 0 & +2 & 0 & 240.6 & 12.7 \\
\hline 29 & 23 & Centre & 0 & 0 & 0 & 0 & 210.5 & 12.7 \\
\hline 7 & 24 & Factorial & -1 & +1 & +1 & -1 & 230.4 & 13.4 \\
\hline 30 & 25 & Centre & 0 & 0 & 0 & 0 & 210.8 & 12.8 \\
\hline 16 & 26 & Factorial & +1 & +1 & +1 & +1 & 220.8 & 12.7 \\
\hline 8 & 27 & Factorial & +1 & +1 & +1 & -1 & 210 & 13.2 \\
\hline 20 & 28 & Axial & 0 & +2 & 0 & 0 & 180.5 & 13 \\
\hline 23 & 29 & Axial & 0 & 0 & 0 & -2 & 190.5 & 13.2 \\
\hline 19 & 30 & Axial & 0 & -2 & 0 & 0 & 180.4 & 12.5 \\
\hline \multicolumn{9}{|c|}{ Carbonized wool } \\
\hline & & & & & & & - & 17.10 \\
\hline
\end{tabular}

which is of utmost importance when optimization is to be considered. We have tested other evaluation methods, in particular, the weight loss and the remaining sugars on the treated substrate but they showed, however, poor correlation and accuracy. Although, this analytical method could not have been applied to the carbonized wool because it is a dry procedure in which the fabric is impregnated with an acid solution in a padding system (foulard) and then "burned" in a dryer at $120^{\circ} \mathrm{C}$ during $20-30 \mathrm{~min}$, according to the ratio and type of plant residues. Moreover, in this case, the plant residues are not dissolved or dispersed in an incubation solution, making impossible to detect the fraction of the soluble reducing sugars (RS).

In this way, SEM analysis was also performed in order to better elucidate not only the damaged caused in the different types of cell walls but also to compare with carbonized wool performed according to the following conditions:

The wool fabric is impregnated in a foulard using a solution of sulphuric acid ( $35 \mathrm{~g} / \mathrm{L}$ and $1.5 \mathrm{~mL} / \mathrm{L}$ of Plurafac LF400) at $18^{\circ} \mathrm{C}$ and an impregnation ratio of 50\%, during $1 \mathrm{~min}$. The acidify fabric follows, in a continuous way, for a drying chamber and is then dry over at $120^{\circ} \mathrm{C}$ for $30 \mathrm{~min}$.

The evaluation of wool damage eventually caused by the enzymatic treatments and by the conventional carbonization was determined by testing a standardized method, the alkali solubility (AS) of wool $[39,40]$. A significant increase in AS of the enzymatically treated or carbonized wool reveals important fiber degradation.

\subsubsection{Experimental design}

The optimization of the enzymatic process was possible using the experimental design techniques and was developed after pre- liminary experiments were performed. $2^{\mathrm{N}}$ Factorial designs were first used to test the influence of enzyme concentration. In those preliminary assays the results have demonstrated that the application of the enzymes in equal parts led to higher plant degradation but also indicated curvature which means that the experimental points are better adjusted by a higher order polynomial, as for instance, a second order one.

Accordingly, a Central Composite Design was implemented in order to determine the optimal conditions with the four design factors. In general, central composite designs involve a total of $\left(2^{k}+2 k+n\right)$ runs, where $k$ is the number of the factors selected, $2^{k}$ are the factorial points of the design, $2 k$ the face-centred points and $n$ is the number of replicates carried out at the centre. Response surface methodology has been widely and successfully used in the optimization of bioprocesses, because enables not only to find for the optimum conditions but also to evaluate the effect of each process factor and to build predictive models [25-27].

In this way, the analysis of the effect of the four factors: $\mathrm{pH}(A)$, temperature $(B)$, enzyme concentration $(C)$ and wetting agent concentration $(D)$, varying each one at 5 levels as showed in Table 2 , resulted in a total of 30 experimental points (Table 3), with 6 replications at the centre. The two responses selected were the amount of reducing sugars liberated after enzyme incubation, to analyze the plant residues degradation and thus the efficiency of the method, and the alkali solubility of wool, to evaluate wool fiber degradation, since they have demonstrated good correlation in the preliminary assays.

Using this design, a second-order polynomial regression model of the data was used to generate predicted responses.

The second-order model is widely used in response surface methodology $[24,25,27]$. The general equation for response $\eta$ of the 
second-order model is given by:

$\eta=\beta_{0}+\sum_{i=1}^{k} \beta_{i} x_{i}+\sum_{i=1}^{k} \beta_{i i} x_{i}^{2}+\sum \sum_{i<j=2}^{k} \beta_{i j} x_{i} x_{j}$

where $k$ is the number of factors, $x_{i}$ are the coded variables and $\beta$ are coefficients.

Data was analyzed using Design Expert ${ }^{\circledR}$ software from Statease, to yield regression equations, regression coefficients and analysis of variance (ANOVA).

The relationship between the response and the variables (factors) is visualized by a response surface or contour plot to see the relative influence of the parameters, to find an optimum parameter combination, and to predict experimental results for other parameter combinations.

\section{Results and discussion}

Optimization and empirical modeling was possible after appropriate experimental design was drawn and experimental trials were run. This powerful statistical approach was of great importance to establish the optimum conditions of the enzymatic process.

The results obtained after the 30 trials of the statistical design and the design layout are shown in Table 3. The fit of the model variables were performed by regression methods and backward elimination.

Therefore, the optimization of the parameters of the enzymatic process was able to be defined analyzing the effect of each factor (parameter) in the degradation of the plant residues and in the prevention of wool damage.

\subsection{Efficiency of the enzymatic method analyzed by RS (reducing sugars) response}

Analyzing the results for RS response, the analysis of variance (Table 3 ) demonstrates that the model is highly significant $(p<0.0001)$, having the residuals distributed along a well randomized straight line, and the $R^{2}$ value, being the measure of the goodness of fit of the model, indicates that $92.92 \%$ of the total variation is explained by the model having a high correlation. The $p$-value 0.1459 for the lack of fit, demonstrates that the model showed no lack of fit. The coefficients of the variables included in the model for RS response have showed a highly significance level $(p<0.05)$. All the others, presenting a low significance level $(p>0.05)$ detected by Student- $t$-test, were excluded from the model.

The adjusted model for RS is indicated in Eq. (2), as well as the significance level of the coefficients:

$$
\begin{aligned}
\mathrm{RS}= & 206.77+{ }^{\mathrm{b}} 9.21 A-{ }^{\mathrm{d}} 7.45 B+{ }^{\mathrm{a}} 37.45 C-{ }^{\mathrm{c}} 8.81 A C-{ }^{\mathrm{a}} 11.47 A^{2} \\
& -{ }^{\mathrm{d}} 5.17 B^{2}-{ }^{\mathrm{d}} 6.38 C^{2}
\end{aligned}
$$

$\left({ }^{\mathrm{a}} p<0.0001 ;{ }^{\mathrm{b}} 0.0001<p \leq 0.001 ;{ }^{\mathrm{c}} 0.001<p<0.01 ;{ }^{\mathrm{d}} p<0.05\right)$.

Further, ANOVA for variables in the model (Table 4 ) and the significance level of the coefficients of the model as well as their values (Eq. (2)) showed that the linear effect of enzyme concentration was considerably higher than the other effects $(p<0.0001)$. The quadratic effect of $\mathrm{pH}$ also has a high contribution in the RS variation. There is a considerable interaction between $\mathrm{pH}$ and enzyme concentration $(0.001<p<0.01)$ meaning the effect of one of the factors depends on the level of the other factor. The wetting agent factor was not included in the model because it was not significance and showed no effect in plant degradation, evaluated by the reducing sugars content, after incubation.

The effect of each factor on the response RS is better elucidated by the response surfaces and contour plots.
Table 4

ANOVA for the representative adjusted model of RS (reducing sugars)

\begin{tabular}{lrrrrr}
\hline Source & Sum of squares & d.f. & Mean square & $F$ ratio & $p$-Value \\
\hline Model & 42952.06 & 7 & 6136.01 & 41.27 & $<0.0001$ \\
$A:$ pH & 2036.88 & 1 & 2036.88 & 13.7 & 0.0010 \\
$B$ : Temperature & 1333.55 & 1 & 1333.55 & 8.97 & 0.0067 \\
C: Enzyme & 33667.55 & 1 & 33667.55 & 226.44 & $<0.0001$ \\
$A C$ & 1240.80 & 1 & 1240.80 & 8.35 & 0.0085 \\
$A^{2}$ & 3684.05 & 1 & 3684.05 & 24.78 & $<0.0001$ \\
$B^{2}$ & 748.56 & 1 & 748.56 & 5.03 & 0.0352 \\
$C^{2}$ & 1140.81 & 1 & 1140.81 & 7.67 & 0.0112 \\
Residual & 3270.96 & 22 & 148.68 & & \\
Lack of fit & 2940.46 & 17 & 172.97 & 2.62 & 0.1459 \\
Pure error & 330.49 & 5 & 66.10 & & \\
Total & 46223.01 & 29 & & & \\
\hline
\end{tabular}

$R^{2}=0.9292$.

In Fig. 1 the response surface plot indicates a optimum enzyme activity around $\mathrm{pH} 4$ using an enzyme concentration for high coded values (+1), i.e. $20 \mathrm{~mL} / \mathrm{L}$ (57.43 FPU/g of Celluclast). In these conditions the reducing sugars amount is $240.60 \mathrm{mg} / \mathrm{g}$ of glucose mass equivalent. This is in accordance to results from other studies, although considering different substrates. Studies evaluating the influence of enzyme loading on the hydrolysis of steam-pretreated softwood demonstrated that optimal conditions for the production of fuel ethanol, also using Celluclast $1.5 \mathrm{~L}$ were at very high enzyme loading (120 FPU/g) [41]. It was also detected the higher effect of enzyme concentration when compared to the one's of $\mathrm{pH}$ factor or temperature [41].

Other authors [38] when studying the enzymatic hydrolysis of acid pretreated rye straw and bermudagrass for ethanol production, with cellulases from $T$. reesei (EC 3.2.1.4), concluded that an excessive enzyme loading of $25 \mathrm{FPU} / \mathrm{g}$ of dry mass of acid pretreated rye straw, incubated after $90 \mathrm{~min}$, resulted in an amount of soluble reducing sugars of $180 \mathrm{mg} / \mathrm{g}$ of glucose mass equivalent.

Our results led to higher amounts of RS, although with higher enzyme loading, but still considering the fact of an inexistent acid pretreatment of the wool plant residues. Also, the higher amount should result by the combination loading of cellulases, hemicellulases and pectinases, as predicted in the preliminary assays.

The response surface plots presented at Figs. 2 and 3 indicate the lower effect of temperature in reducing sugars yield,

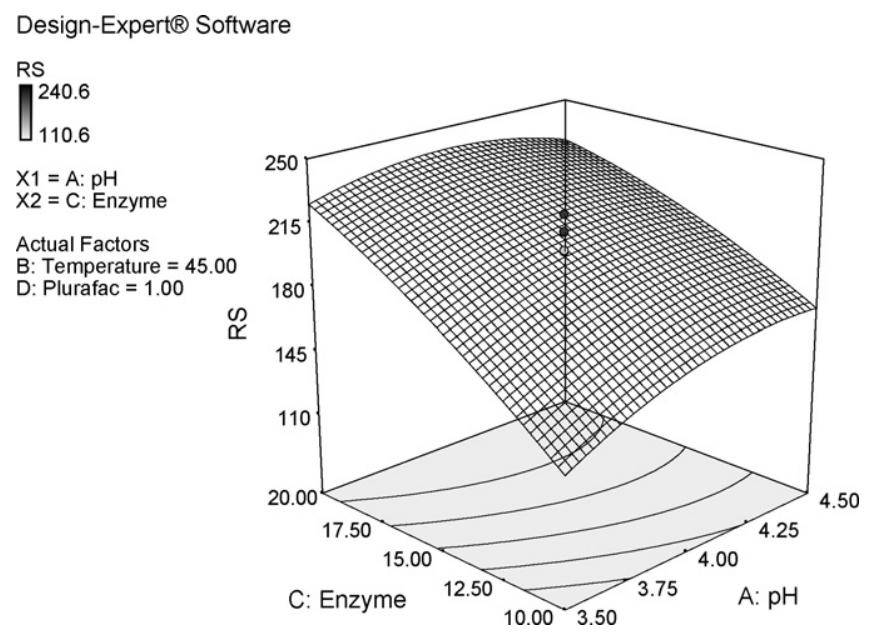

Fig. 1. Response surface for the effect of $\mathrm{pH}$ and enzyme concentration, on the reducing sugars yield (RS). 




Fig. 2. Response surface for the effect of enzyme concentration and temperature, on the reducing sugars yield (RS).

when compared either to enzyme concentration or $\mathrm{pH}$. Also, indicates the optimum temperature around $40-45^{\circ} \mathrm{C}$, nearly identical to the optimal temperature activity for both enzymatic extracts, being in accordance with other studies. Tengborg et al. [41] concluded that the optimal conditions for softwood biodegradation were $\mathrm{pH} 4.9$, temperature $38^{\circ} \mathrm{C}$ during a residence time of $144 \mathrm{~h}$, by using $0.285 \mathrm{~g}$ of Celluclast $1.5 \mathrm{~L}$ per gram of cellulose.

The effect of the wetting agent Plurafac is presented at Fig. 4. We can clearly see no effect on reducing sugars yield, meaning it has any important influence regarding plant residues degradation. Therefore, addition of surfactant to prevent binding of enzymes to residual lignin did not reveal important effect meaning no significant enzyme adsorption to lignocellulose surface occurred, probably caused by the small amount of lignin in plant residues composition. This was an unpredictable result when compared to the one's attained in lignocellulosic materials. Other studies carried out to investigate the mechanism of surfactant effect in enzymatic hydrolysis of steam-pretreated spruce, suggested a better enzyme activity specially when using non-ionic surfactants [35]. However, the material is quite different when compared to ours, especially in what concerns to higher lignin amount in its composition.

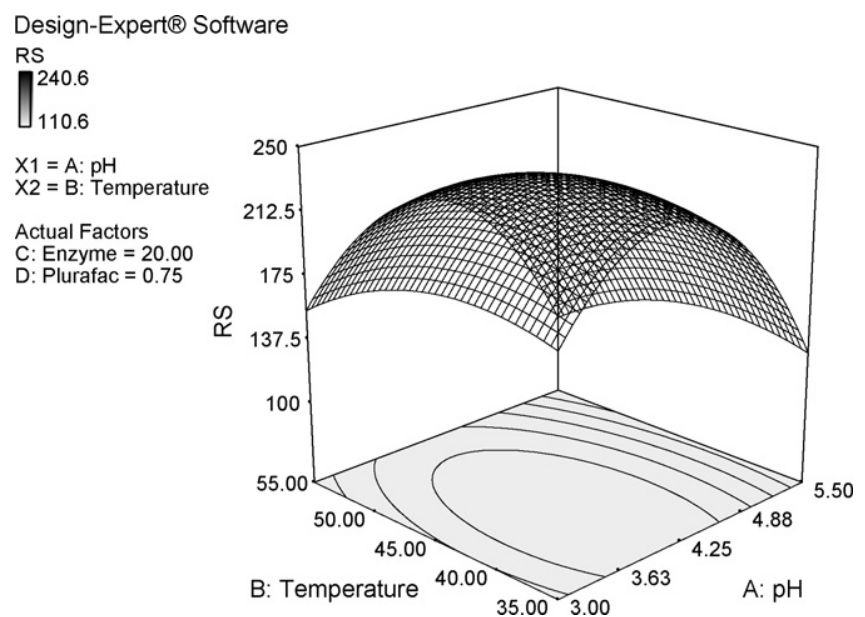

Fig. 3. Response surface for the effect of temperature and $\mathrm{pH}$, on the reducing sugars yield (RS).

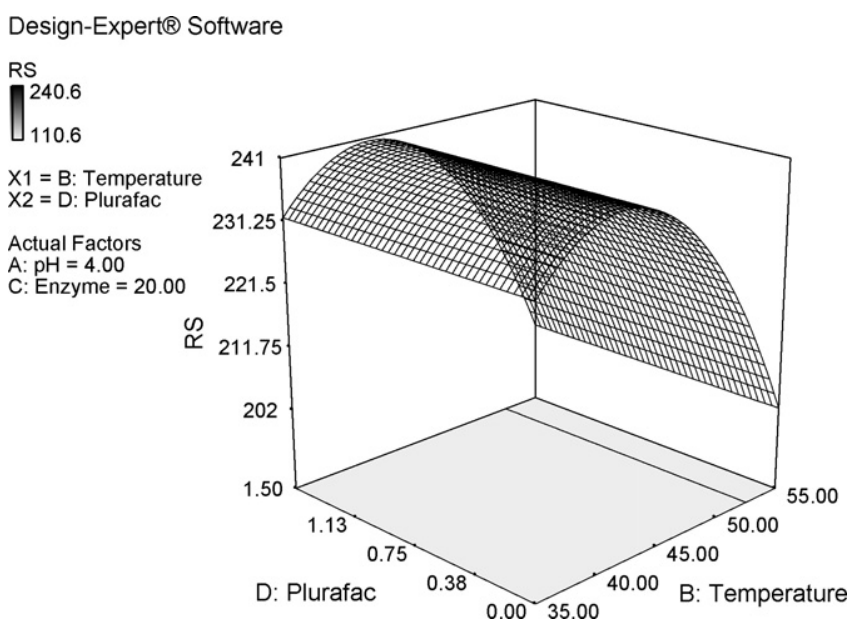

Fig. 4. Response surface for the effect of wetting agent (Plurafac), concentration and temperature, on the reducing sugars yield (RS).

\subsection{Evaluation of quality of wool after enzymatic treatments analyzed by AS (alkali solubility) response}

The analysis of variance for the alkali solubility response (Table 5) demonstrates that the model is highly significant $(p<0.0001)$, having the residuals distributed along a well randomized straight line, and the $R^{2}$ value, being the measure of the goodness of fit of the model, indicates that $80.91 \%$ of the total variation is explained by the model, thus, representing a good correlation. The $p$-value 0.5055 for lack of fit, demonstrates that the model showed no lack of fit. As for the RS response, the coefficients of the variables included in the model for AS response, have showed a highly significance level $(p<0.05)$. All the others, presenting a low significance level $(p>0.05)$ detected by Student- $t$-test, were excluded from the model.

The adjusted model for alkali solubility is indicated in Eq. (3), as well as the significance level of the coefficients:

$\mathrm{AS}=12.66+{ }^{\mathrm{a}} 0.14 \times B-{ }^{\mathrm{a}} 0.21 \times D+{ }^{\mathrm{c}} 0.041 \times B^{2}+{ }^{\mathrm{b}} 0.066 \times D^{2}$

${ }^{\mathrm{a}} p<0.0001 ;{ }^{\mathrm{b}} 0.01<p<0.0025 ;{ }^{\mathrm{c}} p<0.1$

The ANOVA for the variables in the model (Table 5) and the significance level of the coefficients of the model as well as their values (Eq. (3)) demonstrated that the linear effect of Plurafac concentration is the most important factor $(p<0.0001)$, considering AS variation, meaning wool quality is guaranteed when its concentration is high. Also, linear effect of temperature $(p<0.0001)$ represents an important factor for AS variation.

Without significance $(p>0.05)$ the quadratic effect of temperature was included in the model because it is involved in an interaction and to respect model hierarchy.

Table 5

ANOVA for the representative adjusted model of AS (alkali solubility)

\begin{tabular}{llrlrr}
\hline Source & Sum of squares & d.f. & Mean square & $F$ ratio & $p$-Value \\
\hline Model & 1.68 & 4 & 0.42 & 26.49 & $<0.0001$ \\
B: Temperature & 0.48 & 1 & 0.48 & 30.42 & $<0.0001$ \\
$D$ : Plurafac & 1.04 & 1 & 1.04 & 65.79 & $<0.0001$ \\
$B^{2}$ & 0.047 & 1 & 0.047 & 2.96 & 0.0974 \\
$D^{2}$ & 0.12 & 1 & 0.12 & 7.74 & 0.0100 \\
Residual & 0.40 & 25 & 0.016 & & \\
Lack of fit & 0.32 & 20 & 0.016 & 1.10 & 0.5055 \\
$\quad$ Pure error & 0.073 & 5 & 0.015 & & \\
Total & 2.07 & 29 & & & \\
\hline
\end{tabular}

$R^{2}=0.8091$. 


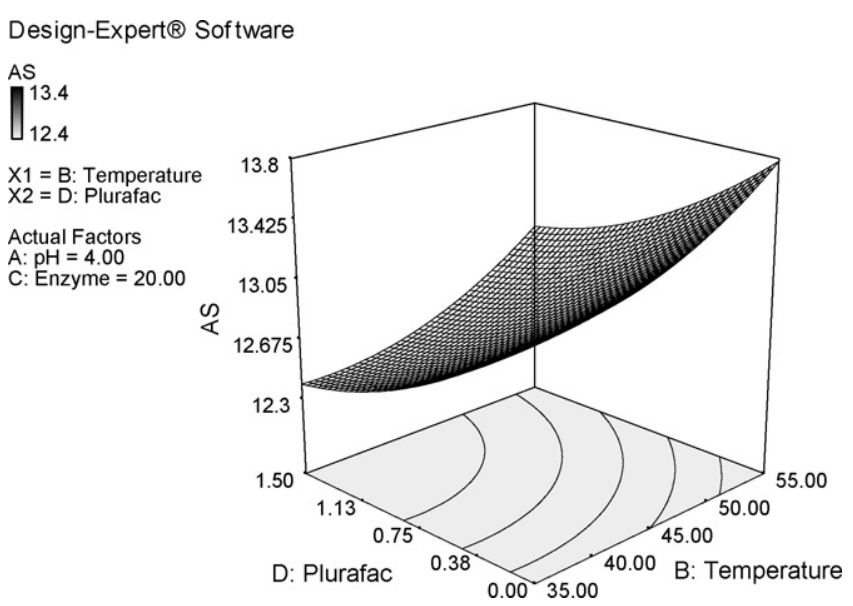

Fig. 5. Response surface for the effect of the wetting agent (Plurafac) concentration and temperature, on the alkali solubility variation (AS).

The effect of each factor on the response AS is better elucidated by the response surfaces and contour plots, as discussed for RS response.

In response surface plotted in Fig. 5 it can be visualized the effect of the wetting agent as well as the effect of the temperature in the AS variation. The manipulation of both factors can be useful in order to prevent wool degradation. The most important effect performed by Plurafac concentration can also be seen.

To higher concentration values up to $1.5 \mathrm{~mL} / \mathrm{L}$ the minimum AS value is achieved, as desirable, indicating an effective wool damage preventing by Plurafac wetting agent. This is an ancient well known effect on wool caused in the presence of surfactant agents, by changing protein conformation, namely by hydrophobic interactions with amino acid side-chains, decreasing the possibility of hydrolysis of the polypeptide chains [2,42].

At Fig. 6 it can be clearly visualize the non-significant effects of $\mathrm{pH}$ and enzyme concentration, thus not included in the quadratic model for AS response. At the selected conditions and levels of the experimental design, no degradation was imparted to the wool. In fact, the values obtained for the alkali solubility of wool were in all trials within the well-known criteria of high quality patterns (less then $14.0 \%$ ) $[39,40]$. In contrary, as expected, for the carbonized wool the alkali solubility found (17.10\%) was within the predictive values for wools treated by this method but clearly out of the high

\section{Design-Expert@ Software}

$\mathrm{SA}$
$\prod_{12.4}^{13.4}$

$\mathrm{X} 1=\mathrm{A}: \mathrm{pH}$

X2 $=$ C: Enzyme

Actual Factors

B: Temperature $=45.00$ D: Plurafac $=1.00$

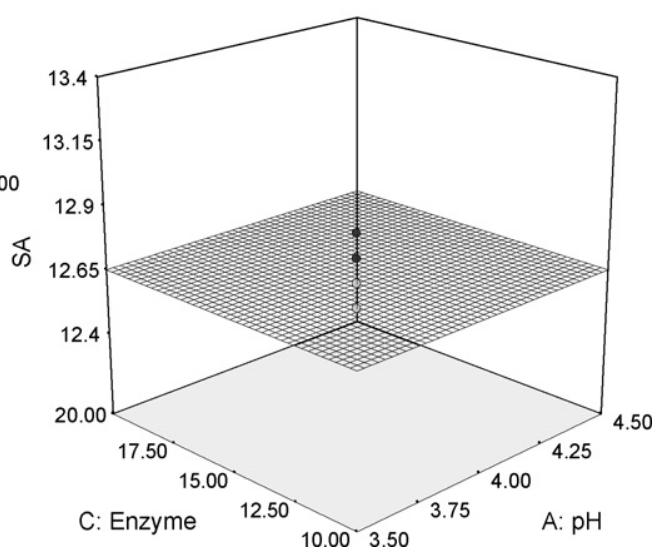

Fig. 6. Response surface for the effect of $\mathrm{pH}$ and enzyme concentration, on the alkali solubility variation (AS). quality patterns $[2,39,40]$ (see Table 3 ). Consequently, the enzymatic process is not only more ecological but also more "wool friendly" because enzymes are not only biodegradable and operate under moderate conditions as they are also highly specific with regards to the substrate.

\subsection{Optimization and validation of the optimized enzymatic process}

Since it was intended to optimize the enzymatic process in order to maximize the yield of the reducing sugars, a maximum for plant residues degradation, and to prevent wool part against any important damage, both responses RS and AS were considered in the graphical optimization option of the Design Expert ${ }^{\circledR}$ software, defining the optimal working conditions to attain high sugar yield, thus, high degradation of the wool residues. The method basically consists of overlaying the curves of the models according to the criteria imposed. The criteria imposed was to maximize RS which should be no less than $240 \mathrm{mg} / \mathrm{g}$ and to minimize AS, having in this study less important impact since the values for AS obtained in the experimental design are commonly found in wools with high quality patterns.

The overlay plot (Fig. 7) shows a non-shaded area where all these criteria are satisfied.

Using a total of $20 \mathrm{~mL} / \mathrm{L}$ of the diluted enzymatic solutions, $\mathrm{pH}$ $4.0,40.56^{\circ} \mathrm{C}$ and $1 \mathrm{~mL} / \mathrm{L}$ of Plurafac, an amount of $240.127 \mathrm{mg} / \mathrm{g}$ glucose mass equivalent is achieved (signalized at the graphic of Fig. 7. as the optimal point) However, considering that the effect of Plurafac is only important on the AS response, since was not statistically significant to be included in the RS empirical model, and regarding economic reasons, we can decrease the Plurafac concentration without significant alteration neither on the reducing sugars yield nor on alkali solubility of wool. In fact, if we consider using about $0.75 \mathrm{~mL} / \mathrm{L}$ of Plurafac wetting agent, the predicted value for RS is still at least $240 \mathrm{mg} / \mathrm{g}$ as settled by the criteria imposed.

The validation assay performed at the optimal conditions attained the following values for the responses, together with the experimental error in the $95 \%$ confidence interval:

$\mathrm{RS}=240.12 \mathrm{mg} / \mathrm{g}[215.20-270.50]$

AS $=12.64 \%[12.41-12.95]$

Thus, the values attained are in good agreement with the predicted values for the analyzed responses, validating the mathematical quadratic models.

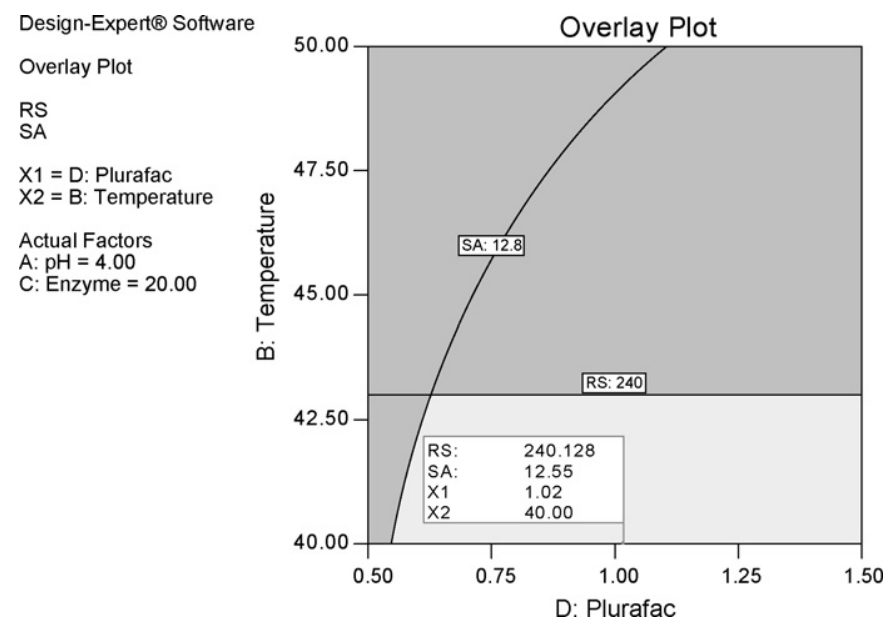

Fig. 7. Optimum region, by overlay plots of the two responses RS and AS, as a function of $\mathrm{pH}$ and temperature. The other factors were kept at the levels showed in the figure. 
2

3

(A)

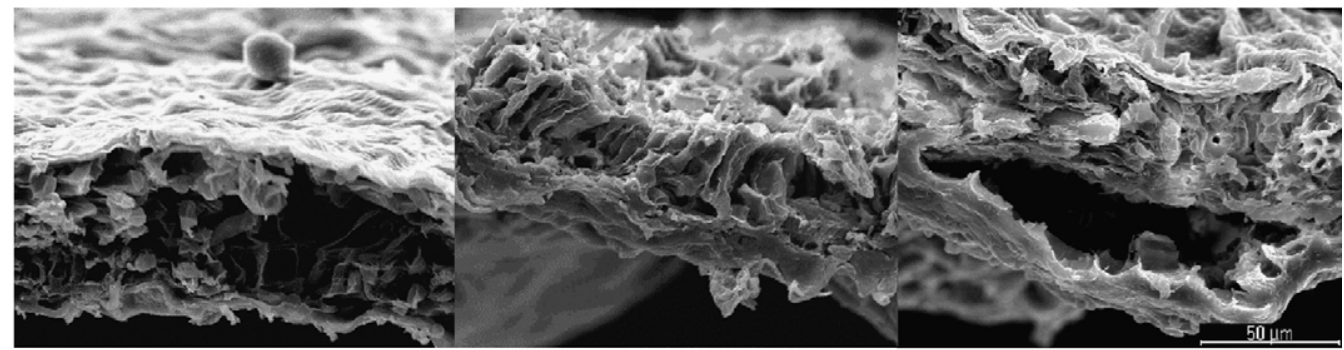

(B)

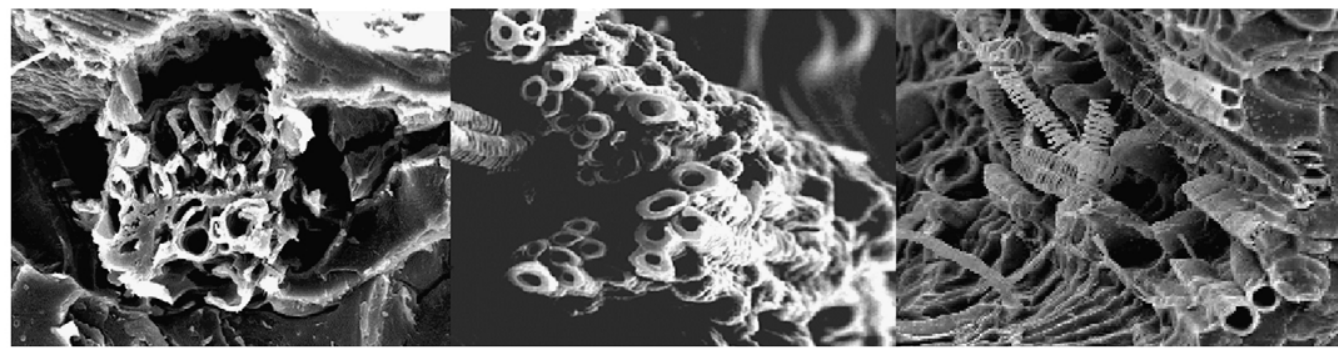

(C)

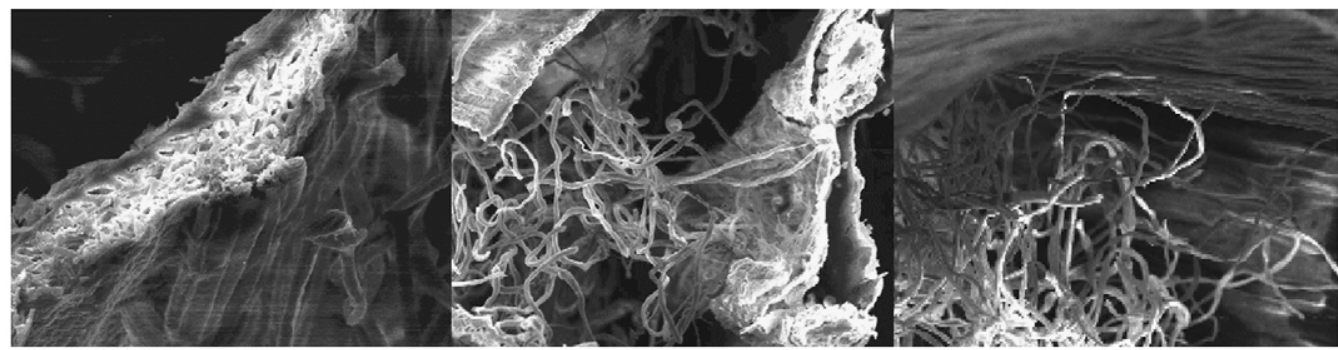

(D)

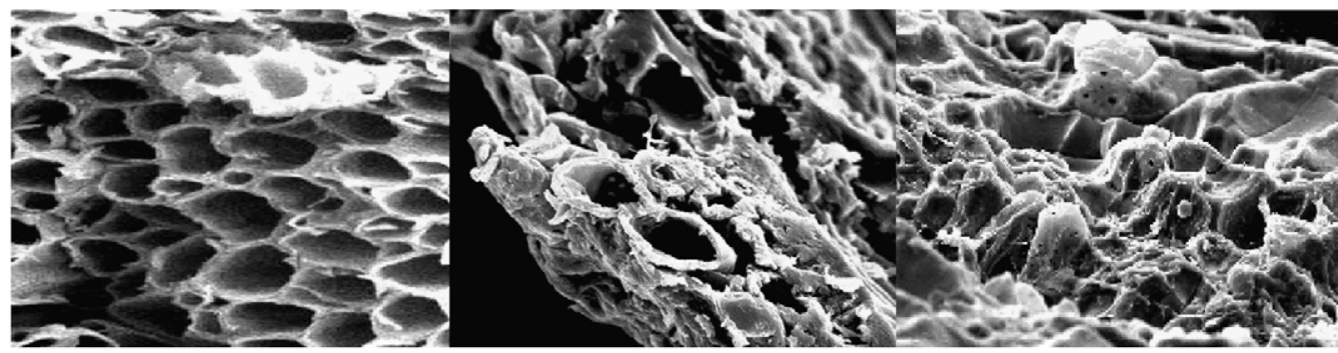

(E)

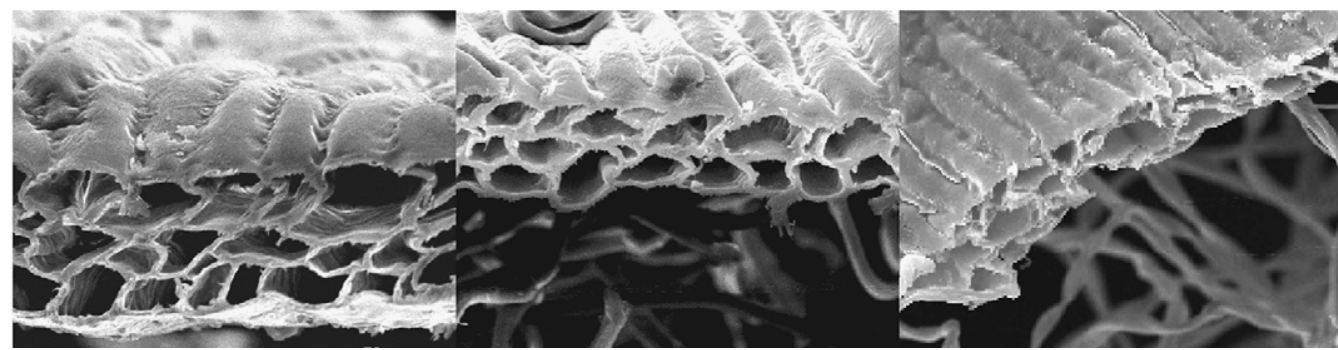

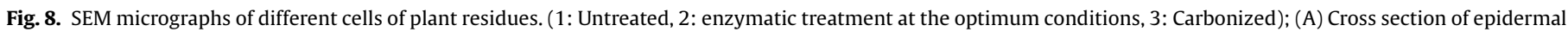

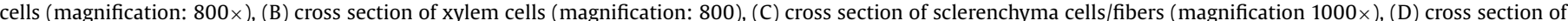
parenchyma cells (magnification: $800 \times$ ); (E) cross section of collenchyma cells magnification: $800 \times$ ).

\subsection{Evaluating the effectiveness of the optimized process, depending on plant cell type}

To better evaluate the degradation caused on the different type of plant cells, detailed image analysis was provided by using a scanning electron microscope.

In Fig. 8, we can observe the damage caused in the middle lamella, primary walls and typical lignin rings (secondary walls of xylem cells [43]) after the optimized enzymatic treatment was per- formed. Also, microphotographs of carbonized residues are shown at column 3 in order to compare. In the epidermal cells presented at Fig. 8 (A2 and A3), known to have thick primary walls tethered firmly together, we can observe the entire degradation of the cuticle and the partial degradation of some parenchyma-dermal cells, eventually more protected by the cuticle layer. In addition, the degradation of the cells is similar either when carbonization or enzymatic process is applied. Looking into sclerenchyma cells, known to have thick and highly lignified secondary walls [43] (C2 
and C3, Fig. 8), we can observe again a similar degradation caused by the enzymes or by the carbonization, respectively. It seems like the selected enzymes have the ability to promote an important splitting and disassembly effect on those cells, as expected. In this case, however, the degradation is mainly regard with the middle lamella mainly composed by hemicelluloses and pectin's [4-8]. The parenchyma cells, characterized by having thin primary walls and shown at Fig. 8 (D2 and D3), reveal an important damaged caused by the enzymes and by the acid and temperature used in the carbonization process. Only few parenchyma cells remain more or less intact. In contrary, other cells appear to remain unbroken after the enzymatic treatment since they have strong lignified secondary walls (B2-lignin rings of xylem vessels). However, the pectic cement of the primary wall and middle lamella has been removed. In the case of the carbonized wool, this type of cells presenting strong secondary walls seems to be more susceptible of being damage (B3).

Enzymatic treatment seems to cause a different damage depending on cell wall type. Primary cell walls are degraded as expected, considering the enzyme selection, while secondary walls remain intact. Thick primary walls (A2 and E2, Fig. 8) also seem to be less susceptible of being degraded, when compared to thin primary walls (D2, Fig. 8). Comparing with the carbonization process, the damage caused by the enzymes is greatly achieved in the several plant cells. Only in the case of the secondary walled cells the damage is less intensive (B3, Fig. 8).

\section{Conclusion}

Enzymatic hydrolysis is a complex process with many parameters that may be varied. This investigation has shown the influence of the most essential parameters for plant residues degradation when enzymatic hydrolysis is considered.

The conventional approach to optimization used for multifactor experimental design is the "one-factor-at-a-time" method, traditionally used by many experimenters. This method has limitations because generates large quantities of data which is time consuming and expensive and especially because ignores interactions among factors, which have a great influence on the responses.

A Central Composite Design was used to estimate the main synergic effects of the $\mathrm{pH}$, temperature, enzyme concentration and of a wetting agent concentration, on the reducing sugars yield after incubation of the substrate as on the alkali solubility of wool.

Response surfaces were drawn from the empirical models and enabled to determine the optimal conditions by graphic optimization performed using the Design Expert ${ }^{\circledR}$ software, and to visualize the method robustness. The experimental results were in good agreement with those predicted by the models.

The optimal conditions for a new and more ecological method to remove plant residues from wool were possible to be defined with this appropriate experimental design. Results demonstrated that enzyme concentration was the most significant effect to achieve the major degradation of the plant residues. The results have also showed much less wool damage when comparing to conventional sulphuric acid carbonization.

Although optimal conditions were investigated and despite a high enzyme loading was use, only part of the total plant residues mass was converted into the correspondent sugars. Primary cell walls are degraded as expected, considering the enzyme selection, although thick primary walls and secondary walls seem to be less susceptible of being degraded, when compared to thin primary walls.

Our results are pioneer in the attempted to relate the damage with the type of plant cell, using SEM analysis and demonstrated that the enzymes are capable to promote an important damage in the plant material. Moreover, biotechnological processes are well known to be useful in industrial biotechnology especially if they are integrated in the processing chain. In accordance, further studies requires the investigation of other possibilities such us the evaluation of subsequent mechanical and chemical processes, currently used in the textile processing of wool in order to better achieve the removal/degradation effect of the undesirable plant residues, after enzymatic process has been performed.

\section{Acknowledgements}

The authors would like to thank the R\&D Unit of Textile and Paper Materials of the University of Beira Interior for the financial support and the Fitecom industries (Covilhã, Portugal) for supplying wool materials and enable to test the optimized process at an industrial scale.

\section{References}

[1] M. Breuers, H. Zahn, The behaviour of synthetic fibres in the carbonization of blended fabrics, Melliand Textilberichte 11 (1983) 788-791 (Eng. Ed.).

[2] W. Zhao, N.A. Johnson, The influence of surfactants in the localized damage of carbonised wool, Textile Res. J. 56 (1986) 741-746.

[3] J. Knott, B. Robinson (Eds.), Wool Carbonising, Eurotex, Guimarães, Portugal, 1994.

[4] L. Taiz, E. Zeiger (Eds.), Plant Physiology, The Benjamin/Cummings Publishing Company Inc., 1991.

[5] D.J. Cosgrove, Assembly and enlargement of the primary cell wall in plants, Annu. Rev. Cell Dev. Biol. 13 (1997) 171-201.

[6] N.C. Carpita, D.M. Gibeaut, Structural models of primary cell walls in flowering plants: consistency of molecular structure with the physical properties of the walls during growth, The Plant J. 3 (1993) 1-30.

[7] D.J. Cosgrove, Wall structure and wall loosening: a look backwards and forwards, Plant Physiol. 125 (2001) 131-134.

[8] M. Pauly, P. Albersheim, A. Darvill, W. York, Molecular domains of cellulose/xyloglucan network in the cell walls of higher plants, The Plant J. 20 (1999) 629-639.

[9] J.-P. Vincken, H.A. Schols, R.J. Oomen, M.C. McCann, P. Ulvskov, A.G. Voragen, If homogalacturonan were a side chain of rhamnogalacturon I. Implications for cell wall architecture, Plant Physiol. 132 (2003) 1781-1789.

[10] P. Albersheim, A. Darvill, K. Roberts, L. Stachelin, J. Varner, Do the structures of cell wall polysaccharides define their mode of synthesis? Plant Physiol. 113 (1997) 1-3.

[11] N. Aro, T. Pakula, M. Penttilä, Transcriptional regulation of plant cell wall degradation by filamentous fungi, FEMS Microbiol. Rev. 6 (2005) 1-21.

[12] S.C. Fry, R.C. Smith, K.F. Renwick, D.J. Martin, S.K. Hodge, K.J. Matthews, Xyloglucan endotransglycosylase, a new wall-loosening enzyme activity from plants, Biochem. J. 282 (1992) 821-828.

[13] L.R. Lynd, P.J. Weimer, W.H. Zyl, I. Pretorius, Microbial cellulose utilization: fundamentals and biotechnology, Microbiol. Mol. Biol. Rev. 66 (2002) 506-577.

[14] R.P. DeVries, J. Visser, Aspergillus enzymes involved in degradation of plant cell wall polysaccharides, Microbiol. Mol. Biol. Rev. 65 (2001) 497-522.

[15] J.A. DeVries, F.M. Rombouts, A.G. Voragen, W. Pilnik, Enzyme degradation of apple pectins, Carbohydr. Polym. 2 (1982) 25-33.

[16] T. Duvetter, A. Van Loey, C. Smout, I. Verlent, B.L. Nguyen, M. Hendrickx, Aspergillus aculeatus pectin methylesterase: study of the inactivation by temperature and pressure and the inhibition by pectin methylesterase inhibitor, Enzyme Microb. Technol. 36 (2005) 385-390.

[17] M.F. González, J.F. Úbeda, R.R. Cordero-Otero, V.T. Gururajan, A.I. Briones, Engineering of an oenological Saccharomyces cerevisiae strain with pectinolytic activity and its effect on wine, Int. J. Food Microbiol. 102 (2005) 173-183.

[18] R.S. Jayani, S. Saxena, R. Gupta, Microbial pectinolytic enzymes: a review, Process Biochem. 4 (2005) 2931-2944.

[19] C. Smout, D.N. Sila, T.S. Vu, A.M.L. Van Loey, M.E.G. Hendrickx, Effect of preheating and calcium pretreatment on pectin structure and thermal texture degradation: a case study on carrots, J. Food Eng. 67 (2005) 419-425.

[20] J. Zhang, G. Henriksson, G. Johansson, Polygalacturonase is the key component in enzymatic retting of flax, J. Biotechnol. 81 (2000) 85-89.

[21] R.A. Arancibia, C.E. Motsenbocker, Pectin methylesterase activity in vivo differs from activity in vitro and enhances polygalacturonase-mediated pectin degradation in tabasco pepper, J. Plant Physiol. 163 (2006) 488-496.

[22] K. Johansson, M. El-Ahmad, R. Friemann, H. Jörnvall, O. Markovic, H. Eklund Crystal structure of plant pectin methylesterase, FEBS Lett. 514 (2002) 243-249.

[23] G.E.P. Box, W.G. Hunter, J.S. Hunger (Eds.), Statistics for Experimenters: an Introduction to Design, Data Analysis and Model Building, John Wiley \& Sons Inc., New York, 1978.

[24] D.C. Montgomery (Ed.), Design and Analysis of Experiments, 4th ed., John Wiley \& Sons Inc., New York, 1997. 
[25] E. Nikerel, E.T. Öner, B. Kirdar, R. Yildirim, Optimization of medium composition for biomass production of recombinant Escherichia coli cells using response surface methodology, Biochem. Eng. J. 32 (2006) 1-6.

[26] N.K. Guthalugu, M. Balaraman, U.S. Kadimi, Optimization of enzymatic hydrolysis of triglycerides in soy deodorized distillate with supercritical carbon dioxide, Biochem. Eng. J. 29 (2006) 220-226.

[27] E.L. Sooa, A.B. Salleh, M. Basri, R.N.Z.A. Rahmana, K. Kamaruddin, Response surface methodological study on lipase-catalyzed synthesis of amino acid surfactants, Process Biochem. 39 (2004) 1511-1518.

[28] J. Buckert, J.M. Koponen, M. Suutarinen, A. Mustranta, M. Lille, R. Torronen, K. Poutanen, Effect of enzyme-aided pressing on anthocyanin yield and profiles in bilberry and blackcurrent juices, J. Sci. Food Agric. 85 (2005) 2548-2556.

[29] International Standard ISO 5983, Methods of analysis of the components of animal feeding stuffs, 1979.

[30] Van Soest, P.J., and J.B. Robertson. 1980. Systems of analysis for evaluating fibrous feeds. p. 49-60. In W.J. Pigden et al. (ed.) Proc. Int. Workshop on Standardization Anal. Meth. Feeds. Ottawa, Canada. 12 -14 Mar. 1979. Unipub. New York.

[31] L.W. Doner, Analytical methods for determining pectin composition, in: M.L. Fishman, J.J. Jen (Eds.), Chemistry and Function of Pectins, ACS Symposium Series 310, Washington, DC, American Chemical Society. Division of Agricultural and Food Chemistry, 1986, pp. 13-21.

[32] N.P. Sheluhhina, L.G. Fedichkina, A rapid method for determination of pectic substances, Acta Bot. Neerl. 43 (1997) 205-207.

[33] G.L. Miller, Use of dinitrosalicylic acid reagent for determination of reduction sugar, Anal. Chem. 31 (1959) 426-428.
[34] T.K. Ghose, Measurement of cellulase activities, Pure Appl. Chem. 59 (2) (1987) 257-268.

[35] T. Eriksson, J. Borjesson, T. Folke, Mechanism of surfactant effect in enzymatic hydrolysis of lignocellulose, Enzyme Microb. Technol. 31 (2002) 353-364.

[36] J.D. Evans, D.E. Akin, J.A. Foulk, Flax-retting by polygalacturonase-containing enzyme mixtures and effects on fiber properties, J. Biotechnol. 97 (2002) 223-231.

[37] S. Moyo, B.A. Gashe, E.K. Collison, S. Mpuchane, Optimising growth conditions for the pectinolytic activity of Kluyveromyces wickerhamii by using response surface methodology, Int. J. Food Microbiol. 85 (2003) 87-100.

[38] Y. Sun, J.J. Cheng, Dilute acid pretreatment of rye straw and bermudagrass for ethanol production, Bioresour. Technol. 96 (2005) 1599-1606.

[39] International Standard IWTO-4, Determination of alkali solubility of wool, 1965.

[40] International Standard IWTO Draft Test Method DRAFT TM-4-00, Method of test for determining the solubility of wool in alkali, 2000.

[41] C. Tengborg, M. Galbe, G. Zacchi, Influence of enzyme loading and physical parameters on the enzymatic hydrolysis of steam-pretreated softwood, Biotechnol. Prog. 17 (2001) 110-117.

[42] J. Knott, H. Zahn, Influence des interactions hydrophobes sur le désacidage des laines carbonisées, Annales Textiles 3 (1970) 22-37.

[43] N. Terashima, T. Awano, K. Takabe, M. Yoshida, Formation of macromolecular lignin in ginkgo xylem cell walls as observed by field emission scanning electron microscopy, Plant Biol. Pathol. 327 (2004) 903-910. 